Discussion Paper No. 14-005

Dynamic Market Power in an Exhaustible Resource Industry. The Case of Rare Earth Elements

Frank Pothen

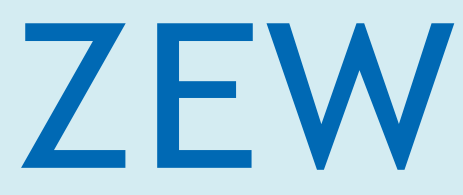

Zentrum für Europäische Wirtschaftsforschung $\mathrm{GmbH}$ Centre for European Economic Research 
Discussion Paper No. 14-005

\title{
Dynamic Market Power in an Exhaustible Resource Industry. The Case of Rare Earth Elements
}

\author{
Frank Pothen
}

Download this ZEW Discussion Paper from our ftp server:

http://ftp.zew.de/pub/zew-docs/dp/dp14005.pdf

Die Discussion Papers dienen einer möglichst schnellen Verbreitung von neueren Forschungsarbeiten des ZEW. Die Beiträge liegen in alleiniger Verantwortung der Autoren und stellen nicht notwendigerweise die Meinung des ZEW dar.

Discussion Papers are intended to make results of ZEW research promptly available to other economists in order to encourage discussion and suggestions for revisions. The authors are solely responsible for the contents which do not necessarily represent the opinion of the ZEW. 


\title{
Dynamic Market Power in an Exhaustible Resource Industry. The Case of Rare Earth
}

\section{Elements}

\author{
Frank Pothen ${ }^{* \dagger}$
}

December 19, 2013

\begin{abstract}
This paper investigates China's capability to exert power on Rare Earth markets until 2020. A dynamic partial equilibrium model allowing for a disaggregated representation of the mining sector and endogenous investment in capacities is developed. The model is calibrated on a novel dataset on Rare Earth mines. Simulations show that Chinese market power is a transitory phenomenon. In 2014 and 2015, Light Rare Earth prices increase by 21 per cent and Heavy Rare Earth prices more than double compared to free trade, if assuming export restrictions to remain unchanged. Market power on Light Rare Earths vanishes almost completely by 2017 due to the entry of new suppliers, while it persists until 2019 for Heavy Rare Earths. Export restrictions imply a loss of Marshallian welfare of US\$ 1.96 billion outside China. In the short run, even moderate cuts in export quotas can increase exerted market power substantially. Altering tariffs induces smaller but more persistent effects. Sensitivity checks indicate that the results are robust, but delayed opening of new mines and demand shocks can be important for China's capability to exert market power.
\end{abstract}

JEL Classifications: F17, Q31, Q37

Keywords: Partial Equilibrium Model, Metals, Rare Earths, Export Restrictions, Exhaustible Resources

*email: pothen@zew.de, tel: +49-621-1235-368, fax: +49-621-1235-226, ZEW, Centre for European Economic Research, Postfach 103443, L 7/1, 68034 Mannheim, Germany.

${ }^{\dagger}$ I am deeply indebted to Florian Landis, Heinz Welsch, Andreas Löschel, Simon Koesler, as well as to the participants of the EAERE conference 2013, the EcoMod 2014, and the participants of seminars at the ZEW and the University of Oldenburg for valuable feedback for previous versions of the paper. The research underlying this study was conducted within the project "Linking Impact Assessment Instruments to Sustainability Expertise (LIAISE)" funded by the European Commission, DG Research as part of the 7th Framework Programme, Grant Agreement 243 826. For more information on financial support, please visit the website of the author (www.zew.de/staff_fpo) and see the annual report of the Centre for European Economic Research. 


\section{Introduction}

Despite serving as an indispensable input for numerous ubiquitous products, from powerful permanent magnets in hard discs to phosphors in TV screens, Rare Earths were virtually absent from public debate until a few years ago. China, which is accounting for more than 90 per cent of worldwide Rare Earth production, changed that recently. The People's Republic tightened its export restrictions on the metals repeatedly from 2005 onwards. Hence, prices have increased continuously and skyrocketed in 2011. Under the impression of these events, more general discussions about the dependency on raw material imports emerged in the US and the EU alike (U.S. Department of Energy, 2011; EU Commission, 2010).

Chinese market power is neither exogenous nor static. If prices are sufficiently high, new suppliers can enter the market, in particular in case of Rare Earths, whose deposits are found in many parts of the worlds. China's export restrictions increase prices in the rest of the world and encourage the expansion of supply. Thus, tight export barriers today can reduce market power in the future. When interpreting China's power on Rare Earth markets, these dynamics have to be taken into account.

In this paper, I investigate to which extend China is able to exert power on Rare Earth markets until 2020 using its trade barriers and which welfare effects they imply. Exerted market power is measured as the price increase relative to a free trade situation. A dynamic partial equilibrium model allowing for endogenous investment in capacities and a disaggregated representation of the mining sector is developed. It represents the physical life cycle of the metals, from the extraction of ores to recycling or disposal. The model is calibrated using a novel dataset on Rare Earth mines. Scenarios are simulated to assess the influence that China's most important policy parameters have on exerted market power: export quotas, export tariffs, and domestic production.

Partial equilibrium models of metal markets can be distinguished into two groups. The first is econometric models including Fisher et al. (1972); Fisher and Owen (1981); Slade (1980) and, more recently, Agostini (2006). This branch of literature proposes aggregate behavioral equations for supply, demand, price formation and recycling. The parameters are estimated econometrically and tested statistically. A second group of studies calibrates partial equilibrium models on metal markets (Winters, 1995; Demailly and Quirion, 2008). A recent example of this approach is Lanz et al. (2013). They develop a model for the global copper market taking into account transportation costs, recycling, and a disaggregated processing sector. It is used to assess carbon leakage induced by 
sub-global sectoral climate policy. These models do not consider endogenous capacity investments.

This paper makes three main contributions. Firstly, it applies a novel dynamic partial equilibrium model to metal markets. Secondly, it provides the first quantitative assessment on China's market power on Rare Earth Elements. Thirdly, it explicitly analyses the dynamic aspects of market power in a raw material sector.

Model simulations indicate that China's power on Rare Earths market is a temporary phenomenon. Its persistence differs by the type of Rare Earths, however. Assuming for status-quo export barriers to remain in place, Chinese market power on Light Rare Earths vanishes around 2016. Market power on Heavy Rare Earths is expected to endure until the end of the decade. Welfare losses outside China due to the export restrictions are US\$ 1.96 billion $^{1}$ until 2020.

Altering China's export quotas has strong effects on prices in the short run, but the People's Republic is unable to exert market power in the long run using quotas. Changing export tariffs has weaker but more continuing effects. Expanding production in China crowds out supply from the rest of the world and makes existing export restrictions more effective. The results are robust to many key assumptions regarding demand and supply of Rare Earths. They are affected strongest by demand shocks and unplanned delays while opening new mines in the rest of the world.

The paper proceeds as follows. Section 2 introduces the Rare Earth Elements. Section 3 presents China's restrictions on Rare Earth exports. The model is outlined in section 4, its results in section 5 . The outcomes of the sensitivity analyses are presented in section 6. Section 7 concludes.

\section{Rare Earths in a Nutshell}

\subsection{Basic Properties}

This subsection provides an introduction to Rare Earth Elements. It draws heavily from Gupta and Krishnamurthy (2005) who give a comprehensive overview of the chemical and physical properties of Rare Earths.

Rare Earths or Rare Earth Elements are a group of 17 metals. They include the Lanthanides, the elements from Lanthanum (Number 57 in the periodic table of elements) to Lutetium (71), plus Scandium (21) and Yttrium (39). Rare Earths are subdivided

\footnotetext{
${ }^{1}$ Billion denotes $10^{9}$ throughout the paper.
} 
into Light Rare Earth Elements and Heavy Rare Earth Elements. The former include Lanthanum (57) to Samarium (62), while the latter consist of Europium (63) to Lutetium (71). Yttrium is included in the Heavy Rare Earths due to its greater similarity to those.

Rare Earths are not rare from a geological point of view. Cerium, the most abundant Rare Earth Element, is roughly as abundant in the Earth's crust as copper. Even the rarest stable Rare Earth, Lutetium, is more plentiful than Gold or Platinum. Heavy Rare Earths are less abundant than Light ones.

Notable deposits of Rare Earths are known in a number of nations. U.S. Geological Survey (2013) estimates total reserves of 110 million metric tons. 48 per cent are located in China. The Chinese government estimates its share of reserves to be much smaller, at approximately 23 per cent (SCIO, 2012). Other important deposits are located in the Commonwealth of Independent States, the US, India, or Australia.

All Rare Earths except Scandium exhibit almost identical chemical properties. This is due to the lanthanide contraction. A characteristic configuration of electrons within the Rare Earths leads to very similar ionic radii. That is responsible for their chemical similarity which makes separating Rare Earths from each other technically challenging and economically costly. The lanthanide contraction also explains why the metals always occur together in their deposits, to a varying degree, however. Occurrences of Rare Earths are either rich in Heavy or in Light Rare Earths.

\subsection{Supply, Demand, and Prices}

Chinese producers dominate the supply of Rare Earth elements. The country accounted for 95 per cent of world production in 2011 and 86 per cent in 2012 (U.S. Geological Survey, 2013). This was not always the case. From the mid-1960s to the mid-1980s, the Mountain Pass mine in California was the most important source of Rare Earths worldwide. China entered the market in the late 1970s. Most of its extraction stems from the Bayan Obo mine in the Inner Mongolia Autonomous Region. China has further increased its output of Rare Earths over the following decades, eventually forcing foreign competitors to exit the market (Hurst, 2010). Until very recently, only a few fringe producers have been supplying Rare Earths outside China. Figure 1 shows the production of Rare Earths by region in (metric) tons per year (tpa) from 1960 to 2011.

A large number of firms is currently trying to enter the Rare Earth market. Hatch (2013b) lists 47 mining projects in 15 countries which published resource estimates based on international standards in July 2013. More than 400 mining projects aim at setting 


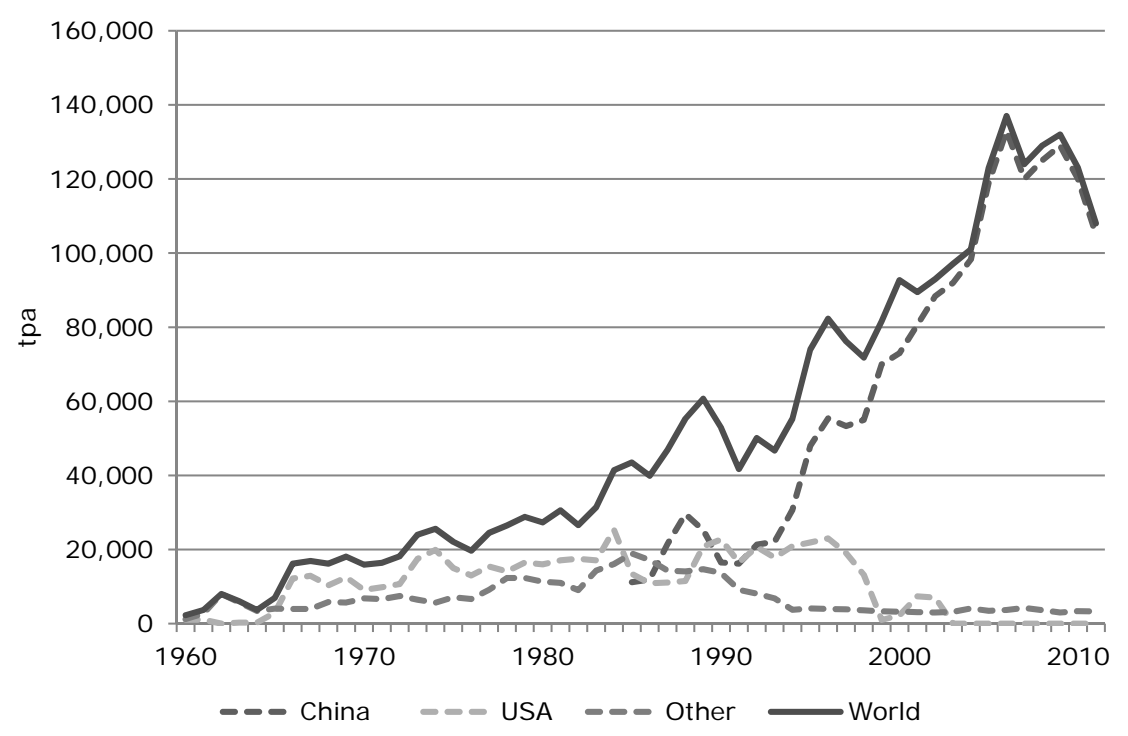

Figure 1: Global rare earth production by region in tpa

Source: U.S. Geological Survey (2012)

up a Rare Earth mine (Hatch, 2012a). Constructing a mine necessitates substantial sunk costs, which act as barrier to entry (Kessides, 1990). Rare Earth mining firms usually conclude long-term contracts to sell their output which reduces risks and eases entry.

Recycling plays a negligible role for Rare Earth supply (Du and Graedel, 2011; Schüler et al., 2011). There is some re-melting of scrap accruing in the production of permanent magnets, but no recycling of discarded products containing Rare Earths on an industrial scale.

The metals are employed in a multitude of industries. Products containing Rare Earths include many high-tech goods such as Neodymium-Iron-Boron (NeFeB) permanent magnets, catalysts, or ceramic capacitors. Table 1 provides an overview of the eight main areas of application, lists some exemplary products and the amount of Rare Earth Oxides (REO) used in an application in metric tons per annum (tpa) in 2008. The individual Rare Earths used in each application vary considerably. To reflect this, the last column in table 1 displays the share of Heavy Rare Earth Oxides (HREO) employed in each application. 68 per cent of Rare Earths were consumed in China in 2008 (Kingsnorth, 2012).

Table 2 displays demand projections by Kingsnorth (2012). He forecasts the overall demand for Rare Earths to grow from 105.000 tpa in 2011 to 160.000 tpa in 2016. Annual growth rates differ notably by application, ranging from 2-4 per cent for catalysts to 8-12 per cent for magnets. Alonso et al. (2012) estimate future demand for Rare Earths used in clean technologies, in particular for $\mathrm{NeFeB}$ permanent magnets. They expect demand 


\begin{tabular}{llll} 
Application & Exemplary Products & tpa REO & $\%$ HREO \\
\hline & & & \\
Catalysts & Catalysts for fluid cracking, automotive catalysts & 27,380 & $0 \%$ \\
Glass industry & Polishing powders, colorized or decolorized glass & 28,444 & $3 \%$ \\
Metallurgy & Steel and aluminum alloys & 11,503 & $0 \%$ \\
Phosphors & TV sets, monitors, fluorescent lamps & 9,002 & $81 \%$ \\
Magnets & Permanent magnets in hard discs, wind turbines & 26,228 & $7 \%$ \\
Battery alloys & Nickel-metal-hydride (NiMH) batteries & 12,098 & $0 \%$ \\
Ceramics & Superconductors, Ceramic capacitors & 7,000 & $53 \%$ \\
Other & Paints and pigments, waste water treatment & 7,520 & $21 \%$ \\
& & & \\
\hline
\end{tabular}

Table 1: Applications of Rare Earths

Source: Schüler et al. (2011); U.S. Geological Survey (2011)

for Rare Earths from these applications to grow between 700 and 2.600 per cent over the next 25 years.

\begin{tabular}{lll} 
Application & $\begin{array}{l}\text { Demand 2011 } \\
\text { tpa }\end{array}$ & $\begin{array}{l}\text { Projection } 2016 \\
\text { tpa }\end{array}$ \\
\hline Catalysts & 20,000 & 25,000 \\
Glass & 8,000 & 10,000 \\
Polishing & 14,000 & 18,000 \\
Metal alloys & 21,000 & 30,000 \\
Magnets & 21,000 & 36,000 \\
Phosphors & 8,000 & 12,000 \\
Ceramics & 7,000 & 10,000 \\
Other & 6,000 & 19,000 \\
Total & 105,000 & 160,000 \\
& & \\
\hline
\end{tabular}

Table 2: Demand projections Source: Kingsnorth (2012)

Figure 2 presents the prices of Rare Earths in China and in the rest of the world (RoW), for Light Rare Earth Oxides (LREO, left side) and Heavy Rare Earth Oxides (HREO, right side). Figure 2 shows a first notable price increase for LREO in 2008 and 2009. From mid 2010 to mid 2011, prices grew steadily and peaked in summer 2011. Prices for HREO evolved the same way. In both cases, prices in the rest of the world exceed Chinese levels considerably. In early 2011, for example, Light Rare Earths were around 400 per cent more expensive outside than inside China. Note that LREO prices grew more strongly in relative terms. The export quota for Rare Earths implies a shadow price which is identical for all Rare Earths. LREO prices per $\mathrm{kg}$ are lower than those of HREO, thus the shadow prices yields higher price increases. 


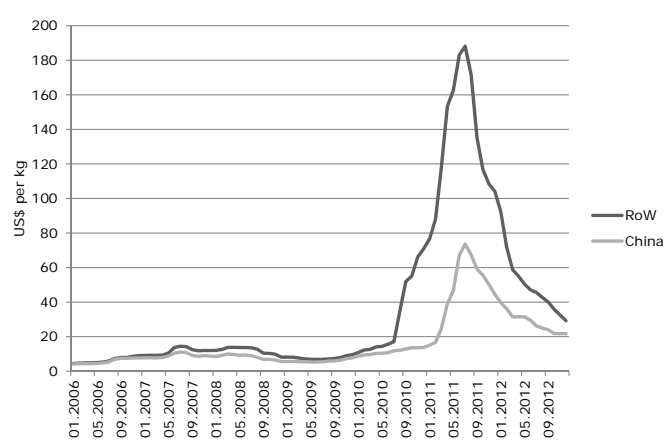

(a)

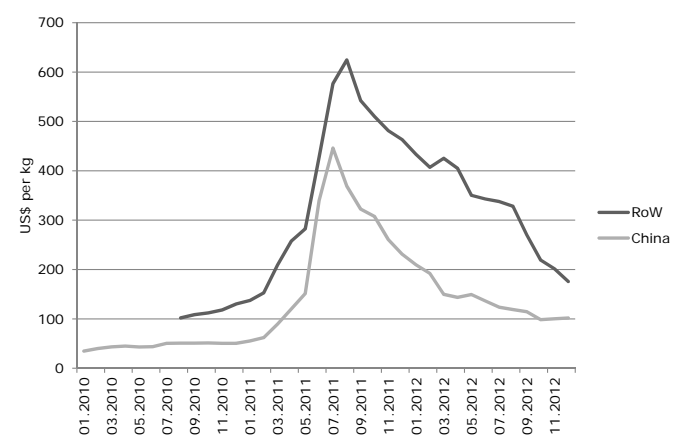

(b)

Figure 2: Real prices of LREO and HREO in US\$ per kg

Source: asianmetal.com

\section{Chinese Export Restrictions on Rare Earths}

Already in 1990, the Chinese government declared Rare Earths a strategic mineral. Foreign firms are banned from all mining, smelting, and separating activities, unless they form a joint venture with a Chinese company (Tse, 2011). A number of barriers to Rare Earth exports were erected thereafter.

China levies ad-valorem taxes on Rare Earth exports. They range from 15 to 25 per cent and are imposed on ores, intermediate products, pure metals, and alloys containing Rare Earth Elements (Tse, 2011). A 16 per cent value added tax refund on exports of unprocessed Rare Earths was abolished in 2007 (Korinek and Kim, 2010). Effective export taxes are between 34.5 and 46 per cent.

Quotas limit Rare Earth exports quantitatively. They have been tightened gradually over the last years, from 65,600 tpa in 2005 to 31,000 tpa in 2012. The Chinese government introduced separate export quotas for Light and Heavy Rare Earths in 2012. Quotas remained virtually unchanged in 2013 (Hatch, 2013a). Figure 3 shows the export quotas in tpa from 2005 to 2013.

Export licenses are allocated by the Ministry of Commerce (MOFCOM). Firms applying for licenses have to fulfill some conditions including compliance to environmental and social security standards. The MOFCOM can withhold or cancel licenses if a firm does not pass inspection by the Ministry of Environmental Protection (Liu and Maughan, 2012). According to the United States' delegation at the World Trade Organization, China uses the licensing mechanism to enforce a minimum export price system (WTO, 2012).

Notable amounts of Rare Earths were smuggled out of China circumventing the export barriers. Approximately one third of Chinese Rare Earth exports were shipped abroad 


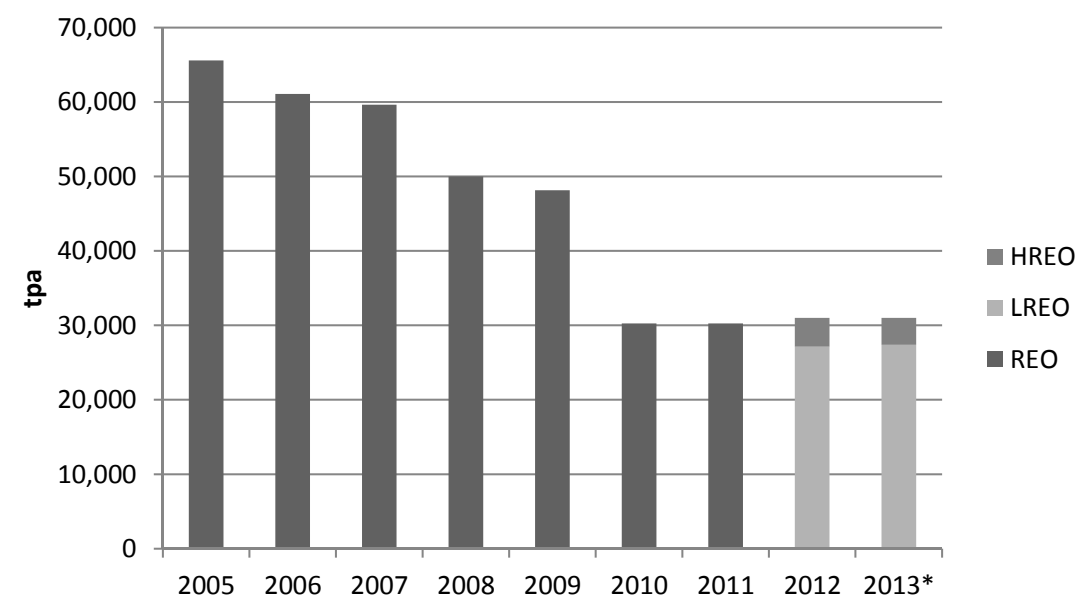

Figure 3: Chinese export quotas 2005 to 2013.

Source: Tse (2011); Hatch (2012b,c, 2013a)

illegally in 2008 (Hurst, 2010). The difference between Chinese and foreign trade statistics fell to 8,000 t in 2011 (Wübbeke, 2013), indicating a decline in smuggling activities.

\section{Model and Data}

\subsection{Model Structure}

\subsubsection{Overview}

A dynamic partial equilibrium model is used to investigate China's power on Rare Earth markets. It replicates the whole physical life cycle of the metals, from the ores in the ground to recycling or disposal. This section provides an overview of the model. See Pothen (2013) for an in-depth description.

Five regions are distinguished in the model. China $(\mathrm{Cn})$, the rest of Asia (RoA), the United States (USA), Europe (EUR) and the other countries (OtC). Scandium as well as Holmium to Lutetium are excluded due to a lack of data. All quantities in the model are measured in Rare Earth Oxides (REO). Each Rare Earth element is modeled individually, but results are usually presented for Light Rare Earths (LREO) and Heavy Rare Earths (HREO). All prices are expressed in 2013 US\$. The model is solved for each year until 2025. Results are presented up to 2020. The model is formulated as a mixed complementarity (MCP) problem and solved using the PATH algorithm (Dirkse and Ferris, 1995).

Four sectors are modeled in each region to depict Rare Earth markets. Mining, trade, 
demand, and recycling. Figure 4 provides an overview of the model structure.

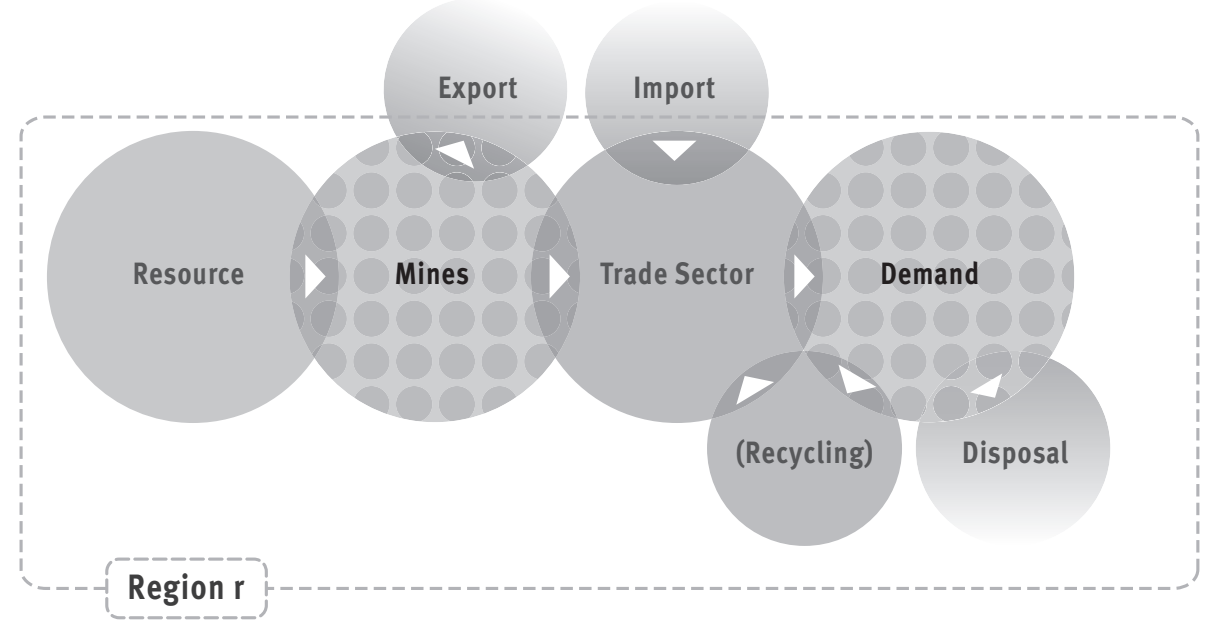

Figure 4: Model structure

\subsubsection{Mining Sector}

The mining sector extracts and processes Rare Earths. It consists of an exogenous number of small price-taking firms, which is indicated by printing the sector dotted in figure 4 . Depicting the mining sector on a firm level is particularly useful in the case of Rare Earths because it reflects the large differences between mines in terms of costs, resource stocks, but also the composition of ores.

Mines maximize their discounted profits over a finite time horizon, choosing their extraction of Rare Earths and their expansion of physical capacities. They are assumed to have perfect foresight of the future. Non-Chinese mines are price takers. They are run by small junior mining firms which do not possess market power in the short run.

Mining firms receive revenues from selling Rare Earths and, if available, by-products. Prices for by-products are exogenous, prices for Rare Earths are endogenous. The share of individual Rare Earth Oxides in a mine's ore is constant. Marginal costs of extraction are assumed to be constant (Agostini, 2006). The mines receive constant marginal revenues for their output.

Extraction is constrained by the resource stock and the capacity available. Each mine possesses a fixed and known resource stock. Adelman (1990) argues that this assumption needs to be relaxed and endogenous investment in exploration and development of new deposits should be allowed for. The assumption of exogenous resource stocks is not expected to bias the results of this study, however. For a time horizon until 2025, deposits considered in the database are sufficient to satisfy any reasonable demand without running into resource constraints. 
The theoretical literature emphasizes the importance of investment costs and endogenous capacities for modeling exhaustible resources sectors (Cairns, 2001; Holland, 2003). Considering endogenous investment is particularly important for the Rare Earth sector, where substantial capacity increases can be expected in the next years. In the model, mines can increase their capacities incurring convex investment costs. The investment cost function is calibrated to replicate proposed mine sizes closely (Pothen, 2013). To reflect the considerable time needed to open up a Rare Earth mine, a lag between the decision to invest and the commencement of production is introduced. Capacities are reduced by 50 per cent in the first year of production to reflect ramp-up times.

Mines extract raw materials if per-unit revenues compensate for the shadow prices of both the exhaustible resource and the capacity constraint. Investing in physical capacities reduces the shadow price of the constraint. Mines invest in capacities as long as the marginal costs of investment are below the gains from relaxing the constraint. For some mines, the marginal costs of investment always exceed the marginal benefits. They do not invest in capacities and thus do not enter the market.

China's Rare Earth production needs to be modeled differently. The mining sector includes some very large producers, in particular the Bayan Obo mine, and is subject to tight and increasing government control. Representing the sector by a number of small, profit-maximizing firms does not appear plausible.

Both the Chinese Rare Earth output and the trade restrictions are assumed to be exogenous throughout the study. Unless specified otherwise, China's extraction is assumed to increase gradually to 150,000 tpa until 2018 and export restrictions correspond to those in 2013.

Two main reasons justify the assumption that China's behavior is exogenous. Firstly, Chinese policy makers have to balance a number of goals when deciding upon Rare Earth extraction and trade policies. These include environmental protection and resource conservation, generation of government revenue, and growth of downstream industries (Wübbeke, 2013; Pothen and Fink, 2013). Postulating a Chinese objective function is likely to oversimplify the policy problem and would yield biased results on China's behavior.

Secondly, deriving China's optimal policy requires solving a differential game between (at least) the People's Republic and the non-Chinese producers. The exact structure of this game is not clear, however. It is, for example, not obvious if China can act as a Stackelberg leader. Deriving Chinese behavior base from a differential game would further 
increase modeling uncertainties.

Assuming Chinese behavior to be exogenous avoids such uncertainties. It allows to investigate the leeway Chinese policy makers have to exert market power without claiming to derive optimal policies for the People's Republic.

Fringe producers of Rare Earths active prior to 2012 are aggregated into a representative mine whose output is held constant. The underlying intuition is that an expansion of production would necessitate substantial investment. If such investment cannot observed, no large increases in output should be expected.

\subsubsection{Trade Sector}

A trade sector in each region depicts trade flows of Rare Earths. It buys primary Rare Earths both at domestic and foreign mines (the import and export flows in figure 4) as well as recycled metals from the domestic recycling sector. The trade sector sells the Rare Earths to the domestic demand sector. It is modeled as a price-taking representative firm.

Chinese export restrictions are implemented at the trade sectors. Tariffs are levied on Rare Earth exports from China. Quotas on Light and Heavy Rare Earths constrain the exports quantitatively. I assume that no smuggling takes place. This reflects a lack of data on costs of smuggling as well as increasing efforts to put a kybosh on illegal exports by the People's Republic (SCIO, 2012).

Transport and other trade costs are neglected. Having export restrictions in place in China but no other trade costs implies the existence of two prices for each Rare Earth, one in China and one in all other places. The latter (aggregate) region is denoted rest of the world (RoW).

\subsubsection{Demand and Recycling}

Rare Earths are used as intermediate inputs in seven applications: catalysts, glass, metallurgy (including batteries), phosphors, magnets, ceramics and other applications. Each application employs different Rare Earths and the respective industries are distributed unevenly across regions. Thus, I model demand as iso-elastic functions specific to application, Rare Earth Oxide, and region. It is calibrated on demand prognoses to account for exogenous increases in demand for Rare Earths. The price elasticity of demand $\epsilon_{t}$ is assumed to be identical over all applications and regions.

If a good containing Rare Earths reaches the end of its useful lifetime, the metals can be recycled. Currently, no recycling of Rare Earths takes place on an industrial scale (Du 
and Graedel, 2011). Costs are prohibitive at current prices and technologies (Meyer and Bras, 2011). In most simulations, recycling costs are assumed to remain prohibitive until 2025 .

The following approach is chosen to investigate how introducing recycling affects China's market power. I assume that products of each application have fixed lifetimes. After the end of the lifetime, they are discarded and become available for recycling. A recycling sector, modeled as a price-taking representative firm, can retrieve the contained Rare Earths. They incur constant marginal costs which is assumed as part of a scenario.

\subsection{Data}

A novel dataset on Rare Earth mines is compiled to calibrate the mining sector. It encompasses the 17 farthest progressed Rare Earth mining projects outside China. Some of those firms announce that they plan to commence production only by the end of the decade. Not considering less progressed projects should not influence the results heavily.

Data is extracted from feasibility studies prepared by mining companies and filed at stock exchanges in the US, Australia, or Canada. Feasibility studies assess if a project is both technically feasible and economically profitable. They include comprehensive geological data, resource estimations, construction plans for the mine, engineering cost estimates, and some market prospectives (Rudenno, 2009). Feasibility studies tend to be optimistic in terms of costs and time-schedules (Noort and Adams, 2006; Mackenzie and Cusworth, 2007) but provide disclosed and verifiable data. All firms having cost estimates available before August 2012 are included in the dataset.

Table 3 presents descriptive statistics on key parameters in the dataset: the mines' resources in $\mathrm{t}$ of $\mathrm{REO}$, the planned capacities in tpa, investment costs in US\$ per tpa capacity, and the operational costs in US\$ per $\mathrm{kg}$ REO. The most striking fact unveiled

\begin{tabular}{lllll} 
& $\begin{array}{l}\text { Resource } \\
\text { (t REO) }\end{array}$ & $\begin{array}{l}\text { Planned capacity } \\
\text { (tpa) }\end{array}$ & $\begin{array}{l}\text { Investment costs } \\
\text { (US\$ per tpa) }\end{array}$ & $\begin{array}{l}\text { Operational costs } \\
\text { (US\$ per kg) }\end{array}$ \\
\hline Min & 70,912 & 4,008 & 19,961 & 2.90 \\
Max & $5,331,400$ & 40,800 & 295,510 & 68.06 \\
Mean & 773,705 & 13,130 & 85,402 & 28.95 \\
& & & & \\
\hline
\end{tabular}

Table 3: Mine data descriptive statistics

by table 3 are the differences among the mines. While the smallest resources stock only encompasses about 70,000 t of REO, the largest contains more than 5 million t. Comparing 
the average deposit size of more than $770,000 \mathrm{t}$ with the annual consumption of about 125,000 tons indicates that exhaustion of Rare Earths is not an urgent problem. Planned capacities range from 4,000 tpa to 40,000 tpa, with an average of about 13,000 tpa.

Investment costs are high, even by the mining sector's standards. They range from US\$20,000 to almost US\$ 300,000 per ton of capacity. Processing facilities account for a large share of investment costs. Extraction costs also vary strongly, between US\$ 3 to US\$ 70 per kg of Rare Earth Oxides. Cost data has to be interpreted with care, however. Costs of extracting and processing by-products are allocated to the Rare Earths, overestimating the costs for mines which sell by-products.

Mines are spread widely in geographical terms. Out of the 17 projects in the database, four are located in the United States and one in the EU. All other projects are in the other countries (OtC) region. Six in Canada, three in Australia, two in Greenland ${ }^{2}$, and one in South Africa.

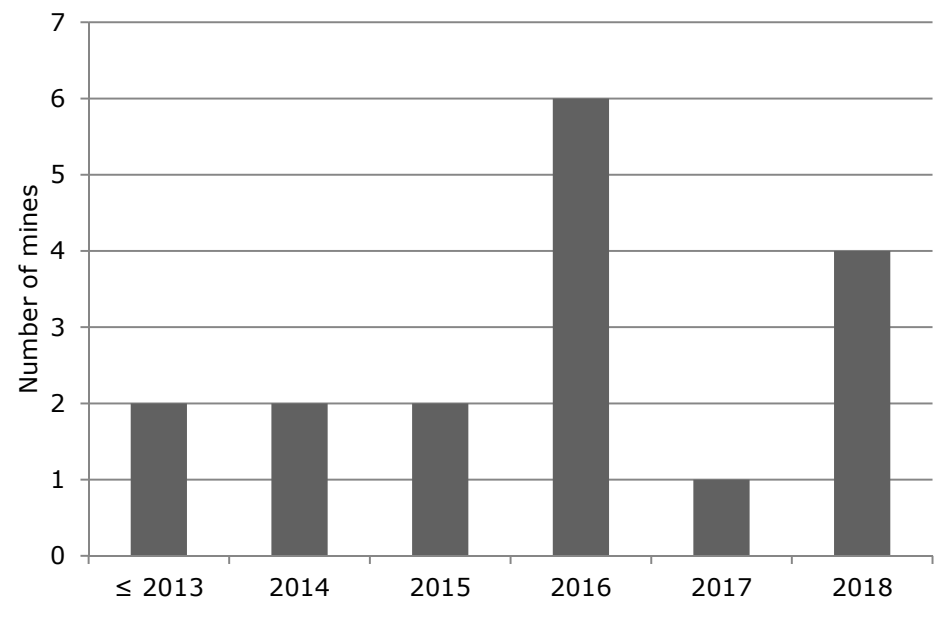

Figure 5: Number of mines planning to commence production per year

Figure 5 shows how many mines announced to commence their production per year. Two mines entered the market already in 2013. Other firms expect to produce only by 2018. The largest number of mines announced their opening for 2016.

The iso-elastic demand functions are calibrated to the estimates by Kingsnorth (2012). Average prices of 2010 are used as reference prices when calibrating the demand function. Shares of individual Rare Earths used in each application are taken from U.S. Geological Survey (2011) and assumed to remain constant. ${ }^{3}$ I assume a price elasticity of demand of $\epsilon_{t}=-0.3$ which grows to $\epsilon_{t}=-0.5$ in 2020 to reflect increasing substitutability over time.

\footnotetext{
${ }^{2}$ Despite being a part of the Kingdom of Denmark, Greenland is not a member of the European Union.

${ }^{3}$ The only exception is the share of Cerium in the application Other. It is increased to reflect the introduction of waste water cleaning technologies heavily relying on Cerium (Kingsnorth, 2012).
} 
These numbers are consistent with estimates for other metals such as copper (Agostini, 2006), Aluminum (Fisher and Owen, 1981), or Zinc (Gupta, 1982). Price data for Rare Earth Oxides inside and outside China comes from asianmetal.com, a private sector firm supplying metal prices.

\section{Results}

\subsection{Business as Usual Scenario}

The first simulation is the business as usual (BAU) scenario. It is assumed that China leaves its export barriers as they are in 2013. Export tariffs vary between 15 and 25 per cent, depending on the individual metal. Value added tax is not deducted for exports. The export quotas add up to about 31,000 tpa. Roughly 27,000 tpa thereof are allocated to Light Rare Earths. Rare Earth supply by the People's Republic grows to 150,000 tpa in 2018. No recycling takes place.

The BAU simulation allows to derive first results on China's exerted market power and implied welfare effects. Both prices and changes in (Marshallian) welfare are calculated in comparison to a hypothetical free trade situation. Subsequently, the effects of changing Chinese policy parameters and the sensitivity of the results to several model parameters are investigated.

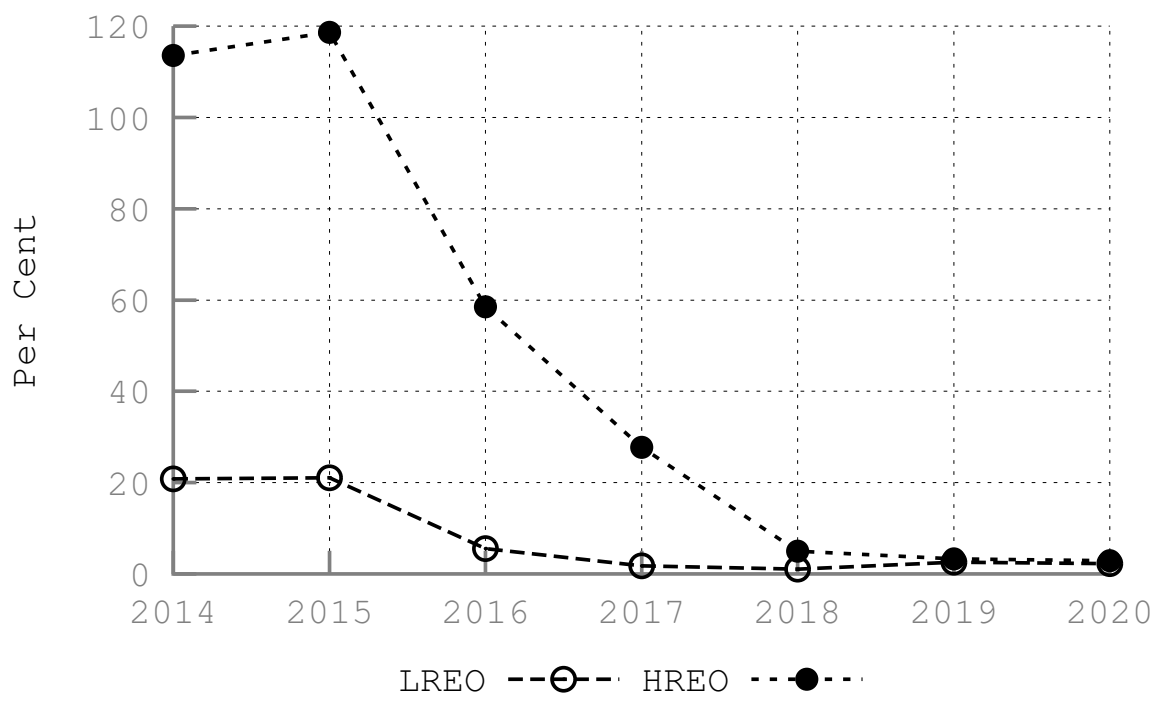

Figure 6: Change of prices in the rest of the world relative to free trade for LREO $\left(\delta p_{w, t}^{L R E O}\right)$ and HREO $\left(\delta p_{w, t}^{H R E O}\right)$ in per cent (BAU)

Exerted market power is measured as the percentage change of prices in the rest of the world compared to free trade. Free trade price levels are calculated by solving the model without any trade restrictions. Exerted market power is analyzed separately for 
LREO $\left(\delta p_{w, t}^{L R E O}\right)$ and HREO $\left(\delta p_{w, t}^{H R E O}\right)$. Recall that prices in all regions except China are identical because no trade costs other than Chinese export barriers are accounted for.

Figure 6 shows how $\delta p_{w, t}^{L R E O}$ and $\delta p_{w, t}^{H R E O}$ evolve under BAU export restrictions. It indicates the temporary nature of China's market power. The People's Republic is expected to have lost its market power by 2019. It is important, however, to differentiate between Light and Heavy Rare Earths. China exerts both weaker and less persistent market power on LREO than on HREO. $\delta p_{w, t}^{L R E O}$ equals 21 per cent in 2014 and 2015, thus prices for LREO in the rest of the world are expected to be 21 per cent above free trade levels. The number declines in 2016 and remains at around 2 per cent thereafter. Heavy Rare Earth Oxides' prices are more than twice as high as they were under free trade until 2015. The markup on prices implied by China's export barriers falls to 58 in 2016 and 27 per cent in 2017. From 2019 onwards, the price difference remains at around 3 per cent.

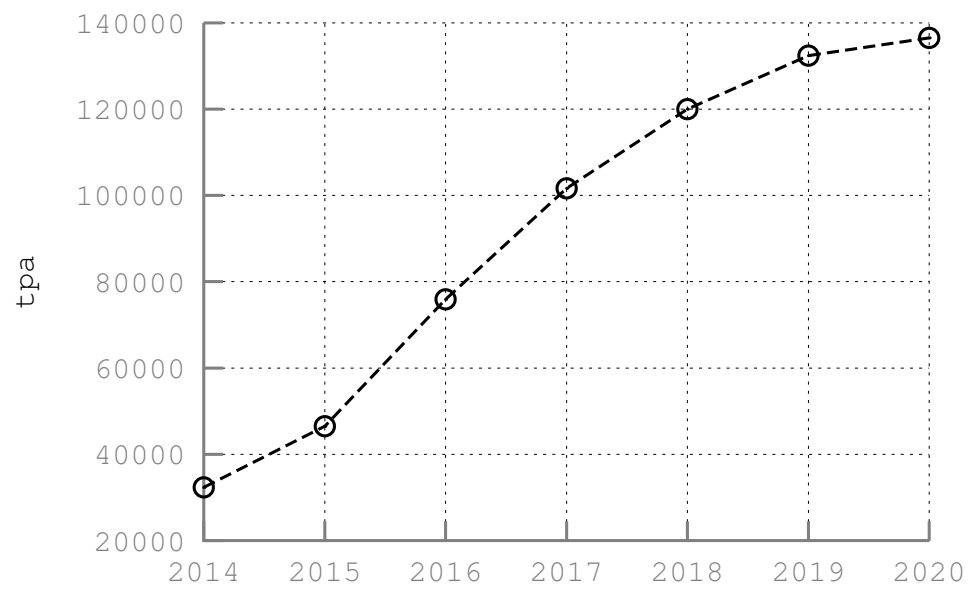

Figure 7: Non-Chinese capacities in tpa

Figure 7 depicts mining capacities outside China in tpa of Rare Earth Oxides. The value increases steadily from about 32,000 tpa in 2014 to 137,000 tpa in 2020 . This corresponds to 48 per cent of worldwide consumption in that year. Non-Chinese capacities are expected to grow particularly strong between 2015 and 2017. They more than double from 47,000 to 102,000 tpa. This explains why China's market power declines heavily in these years. Entry of new suppliers deteriorates the market power which China can exert using its export restrictions.

It is not evident from figure 7 why the export restrictions are more effective for Heavy than for Light Rare Earths. Recall that deposits of Rare Earth Elements are usually rich in Heavy or in Light Rare Earths. All mining projects commencing production until 2017 are rich in Light Rare Earths. Non-Chinese capacities for HREO are below 1,000 tpa until 2016. Larger lags for mines supplying Heavy Rare Earths explains why China can exert 
more market power on the Heavies.

\begin{tabular}{ll} 
Region & $\Delta W_{r}$ \\
\hline China & 1.40 \\
USA & -0.58 \\
Europe & -0.57 \\
Asia except China & -1.46 \\
Other countries & 0.66 \\
World except China & -1.96 \\
& \\
\hline
\end{tabular}

Table 4: Cumulative welfare change by region compared to free trade in billion US\$

$\Delta W_{r}$ denotes the welfare effect implied by China's export restrictions in region $r$. It is measured as the discounted Marshallian welfare change until 2020 in billion US\$ compared to free trade. A high discount rate of 7 per cent is used to reflect the uncertain nature of Rare Earth markets. The numbers need to be interpreted with great care, in particular those for China. Firstly, because data on extraction costs in China is unreliable. Secondly, because welfare losses caused by the environmental damages from mining Rare Earths, which are particularly high in China, are not accounted for.

China realizes welfare gains of US\$ 1.40 billion until 2020 by restricting its Rare Earth exports. The United States, the EU, and the rest of Asia experience welfare losses. The welfare loss in the rest of Asia is the largest $\left(\Delta W_{R o A}=\mathrm{US} \$-1.46\right.$ billion). This region is affected strongly because it is the second largest consumer of Rare Earths and because it lacks domestic supply. Interestingly, the other countries region (OtC) benefits from China's export barriers. It encompasses nations such as Australia, Canada, South Africa, and Greenland. Higher prices increase producer surplus in those countries, leading to a welfare gain. Aggregate welfare changes outside China, denoted $\Delta W_{C n^{\prime}}$, add up to US\$ -1.96 billion. The export barriers distort Rare Earth markets and thus lead to inefficiencies. Total welfare losses from trade restrictions sum up to US\$ 0.56 billion.

After analyzing the business as usual scenario, the effects of changing China's three most important policy parameters are investigated. The export quotas, the export tariffs and the level of domestic production.

\subsubsection{Altering Export Quotas}

The following simulations investigate how exerted market power and corresponding welfare effects are impacted by changes in China's export quota. Three scenarios are conducted. In scenario I, export quotas are reduced to 15,500 tpa (50 per cent less than in the BAU). 
In scenario II, they are increased to 46,000 tpa (50 per cent more than in the BAU). BAU is shown to ease the comparison. All other parameters than the export quotas remain at their BAU levels.

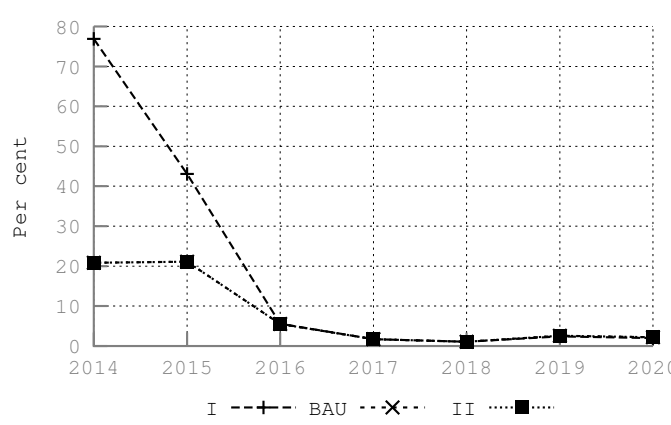

(a)

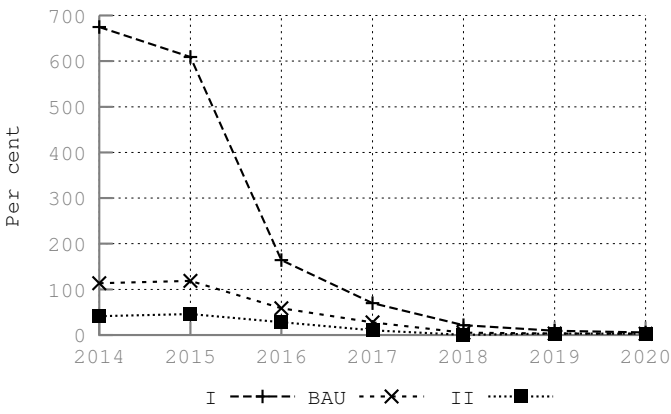

(b)

Figure 8: Change of prices in the rest of the world relative to free trade for LREO $\left(\delta p_{w, t}^{L R E O}\right)$ and HREO $\left(\delta p_{w, t}^{H R E O}\right)$ in per cent (Quotas)

Figure 8 shows $\delta p_{w, t}^{L R E O}$ (left-hand side) and $\delta p_{w, t}^{H R E O}$ (right-hand side) in the three simulations. BAU quotas for Light Rare Earths are non-binding already in 2014. Thus, decreasing them further has no effect on $\delta p_{w, t}^{L R E O}$. Lowering export quotas for LREO raises prices outside China. If they are reduced by 50 per cent (scenario I), $\delta p_{w, 2014}^{L R E O}$ quadruples. The tightened export quotas become non-binding for LREO again already in 2016. Varying export quotas has stronger effects on prices for HREO. They exceed free trade levels by more than 600 per cent in 2014 and 2015 in scenario I, compared to 120 per cent in the BAU. Increasing the quotas by $50 \%$ yields $\delta p_{w, 2014}^{H R E O}=41$ per cent. Though price differences converge from 2016 onwards, varying export quotas has some effect until 2020.

Tightening export quotas undermines Chinese market power in the future. After 2016, when export quotas on Light Rare Earths become ineffective, RoW prices are higher if quotas are less strict. In $2020, \delta p_{w, t}^{L R E O}$ equals 1.88 per cent in scenario I but 2.13 per cent in scenario II. These numbers are small, however, compared to the initial markups in 2014 or 2015. While tighter quotas induce more capacity investment and thus less market power in the future, relaxing them has no notable effect on capacities.

The aggregate welfare changes outside China, $\Delta W_{C n^{\prime}}$, is used to compare welfare effects implied by the quotas. This parameter is used for two reasons. Firstly, because a scalar parameter for welfare changes eases the comparison. Secondly, because results on Chinese welfare are less reliable than those on non-Chinese welfare.

Figure 9 shows $\Delta W_{C n^{\prime}}$ as a function of China's export quotas. The relationship between the size of the quotas and welfare is highly concave. Welfare outside China falls 


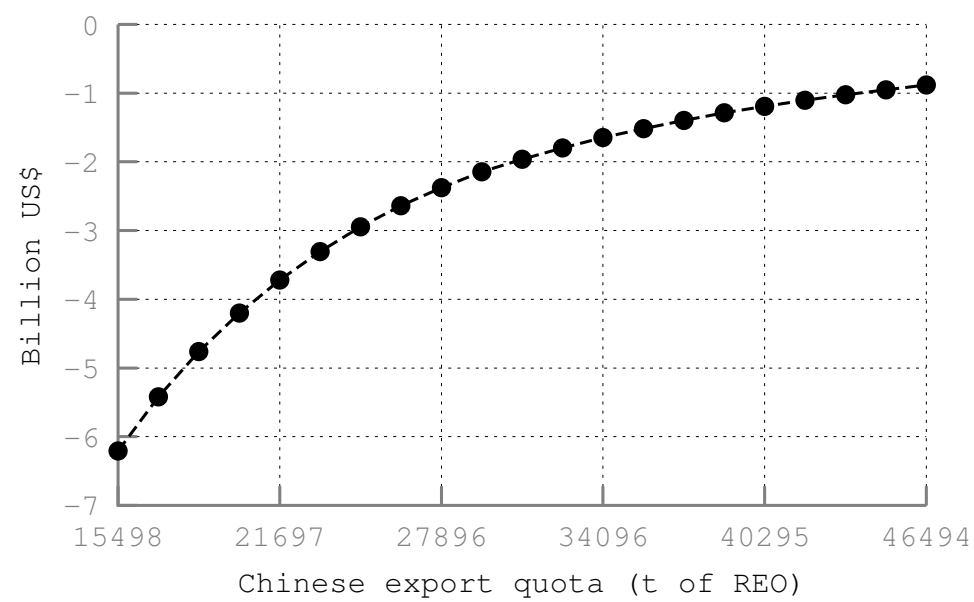

Figure 9: $\Delta W_{C n^{\prime}}$ in billion US\$ as a function of China's export quotas

significantly if quotas are reduced. If they are cut to 50 per cent of BAU levels (scenario I), welfare losses soar to US\$ 6.2 billion. Relaxing them has smaller welfare implications. If the quotas increased by 50 per cent (scenario II), $\Delta W_{C n^{\prime}}$ is reduced by about US $\$ 1.1$ billion to US $\$ 880$ million. If quotas are loosened further, they become non-binding and welfare losses reach US\$ 650 . Welfare reacts elastic on changes in quotas. If the quotas are increased by one per cent from BAU levels, welfare loss falls by 1.7 per cent.

Simulating different export quotas allows for the following conclusions. Tightening them implies high price increases in the short run and large welfare effects. Growing capacities in the rest of the world render quotas ineffective at some point. This process takes longer for Heavy Rare Earths than for the Light ones. Tighter quotas weaken China's market power in the long run, but when it has almost vanished anyway.

\subsubsection{Altering Export Tariffs}

The second set of simulations concerns China's tariffs on Rare Earth exports. They reveal how China's exerted market power changes if tariffs are altered. Three scenarios are presented. Scenario I corresponds to an increase of tariffs by 50 per cent, scenario II to a reduction by 50 per cent compared to BAU. Results of the BAU scenario are presented as well.

Price changes relative to free trade levels are shown in figure 10 for three simulations. $\delta p_{w, t}^{L R E O}$ is displayed in figure $10 \mathrm{a}, \delta p_{w, t}^{H R E O}$ in figure 10b. Varying export tariffs has smaller effects on exerted market power than varying the quota, but effects are more persistent. While quotas become non-binding due to growing supply in the rest of the world, China remains a net exporter of some Rare Earths. Thus, tariffs continue to have 


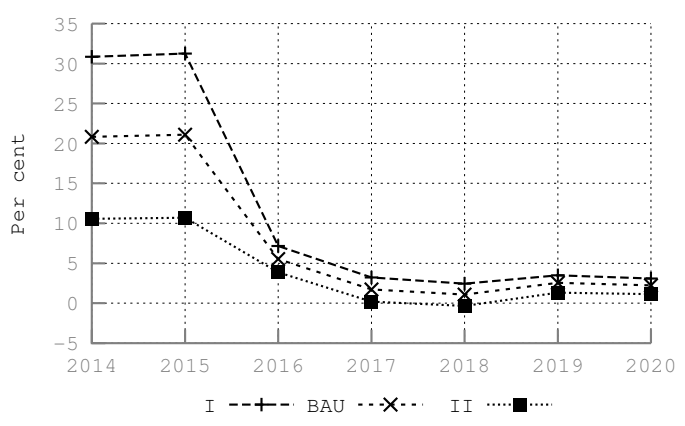

(a)

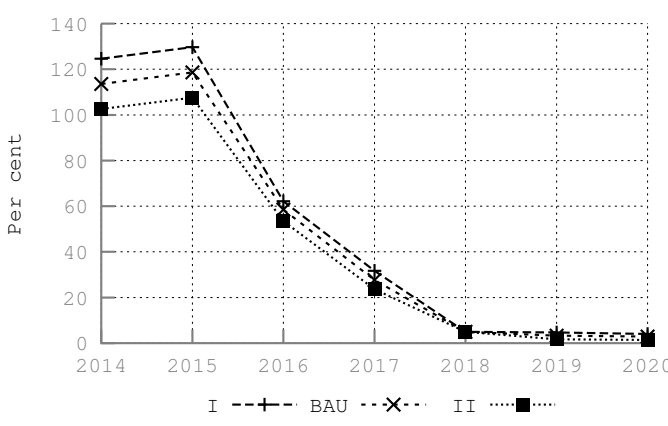

(b)

Figure 10: Change of prices in the rest of the world relative to free trade for LREO $\left(\delta p_{w, t}^{L R E O}\right)$ and HREO $\left(\delta p_{w, t}^{H R E O}\right)$ in per cent (Tariffs)

effects on prices. Effects of raising or reducing tariffs are symmetric. $\delta p_{w, t}^{L R E O}$ increases by 10 percentage points in 2014 and 2015 in simulation 1 and falls by 10 percentage points in simulation 21, for example.

Interestingly, changes in export tariffs influence HREO prices while the quota is still binding. These increases can be attributed to price changes between different Heavy Rare Earths. Relative prices of individual Rare Earths change due to changes in the tariffs. The share of each HREO is held constant when calculating $\delta p_{w, t}^{H R E O}$. Thus, variation in tariffs affects $\delta p_{w, t}^{H R E O}$.

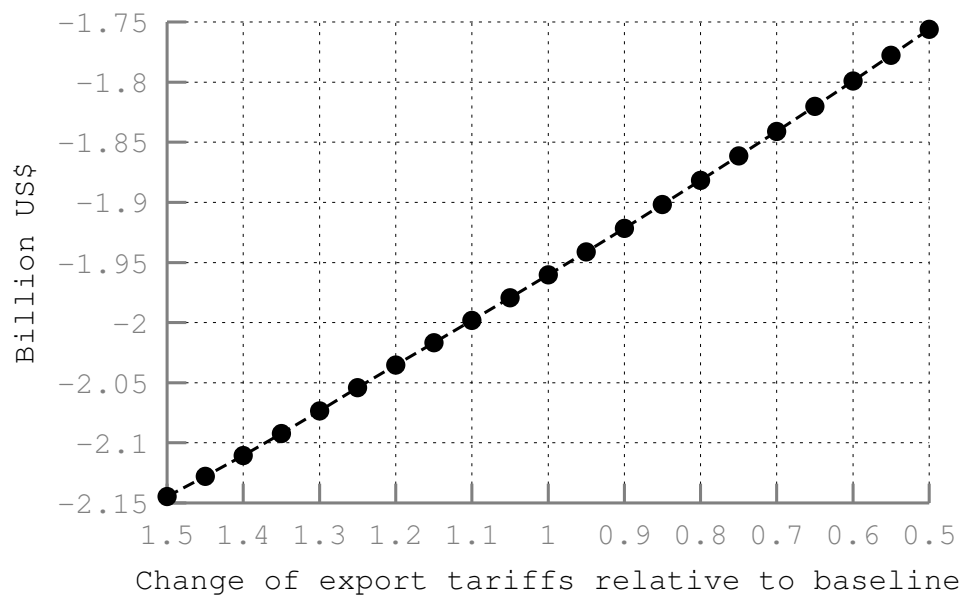

Figure 11: $\Delta W_{C n^{\prime}}$ in billion US\$ as a function of tariff changes

Figure 11 shows $\Delta W_{C n^{\prime}}$ as a function of tariff changes. Welfare grows linearly as tariffs fall. If export taxes are cut to 50 per cent of BAU levels, welfare loss outside China is reduced by US $\$ 200$ million to $\Delta W_{C n^{\prime}}=$ US $\$-1.76$ billion. If they are raised by 50 per cent, $\Delta W_{C n^{\prime}}$ equals US\$-2.14 billion. Welfare reacts less elastic on changes in tariffs than on changes in quotas. The elasticity of $\Delta W_{C n^{\prime}}$ on tariffs at the BAU level is 0.19. 


\subsubsection{Rare Earth Supply}

Further simulations concern the supply of Rare Earths in China. Production of Rare Earth elements is highly regulated and the Chinese government aims at further tightening its control over domestic supply (SCIO, 2012). It is reasonable to perceive Chinese Rare Earth production as a policy variable.

Again, three scenarios are presented. Scenario I corresponds to a 25 per cent increase in Chinese Rare Earth output. The production is reduced in scenario II by 25 per cent, both compared to the BAU. Results of the BAU are shown for comparison as well. Export restrictions remain unchanged in all scenarios.

Note that changing Chinese Rare Earth supply also implies a different free trade situation. Therefore, the respective free trade simulations are conducted for all scenarios. The results do not reveal if expanding or reducing production is beneficial for China, because neither the environmental externalities associated with mining nor the user rents of the resources are accounted for.

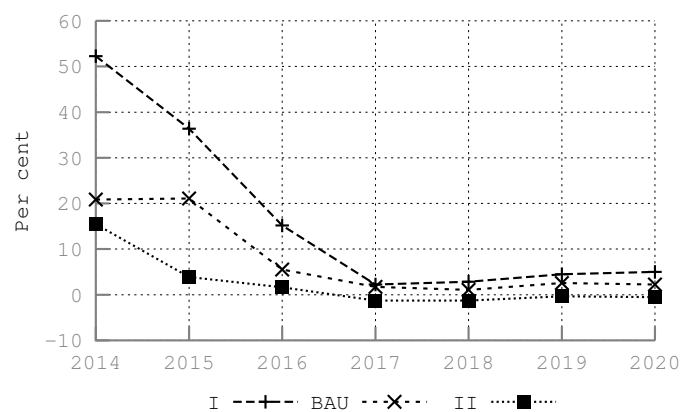

(a)

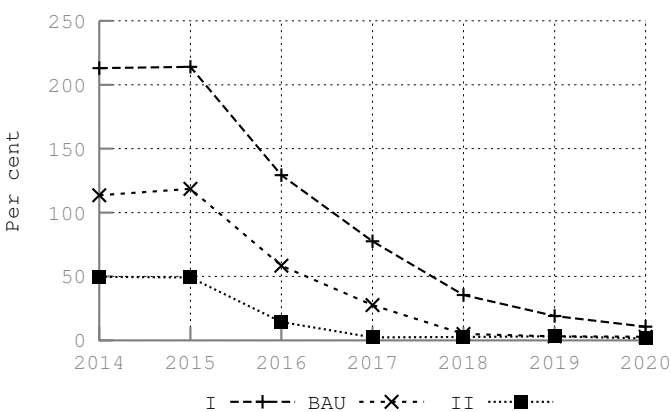

(b)

Figure 12: Change of prices in the rest of the world relative to free trade for LREO $\left(\delta p_{w, t}^{L R E O}\right)$ and HREO $\left(\delta p_{w, t}^{H R E O}\right)$ in per cent (Chinese Production)

Price changes relative to free trade are shown in figure 12. $\delta p_{w, t}^{L R E O}$ is displayed on the left side, $\delta p_{w, t}^{H R E O}$ on the right. Figure 12 indicates that expanding production in China augments exerted market power, both for LREO and HREO. Two reasons explain these results. Firstly, increasing supply of Rare Earths in China renders export quotas tighter in the short run. Higher shadow prices are required to clear the markets. Secondly, increasing Chinese output crowds out new capacities in the rest of the world. If China's supply expands by 25 per cent, non-Chinese capacities in 2020 fall from 137,000 tpa in the BAU to 123,000 tpa. With smaller capacities available, the rest of the world is more exposed to Chinese trade restrictions.

Welfare effects outside China $\Delta W_{C n^{\prime}}$ are shown in figure 13 as a function of changes in Chinese production. Welfare losses in the rest of the world grow when the People's 


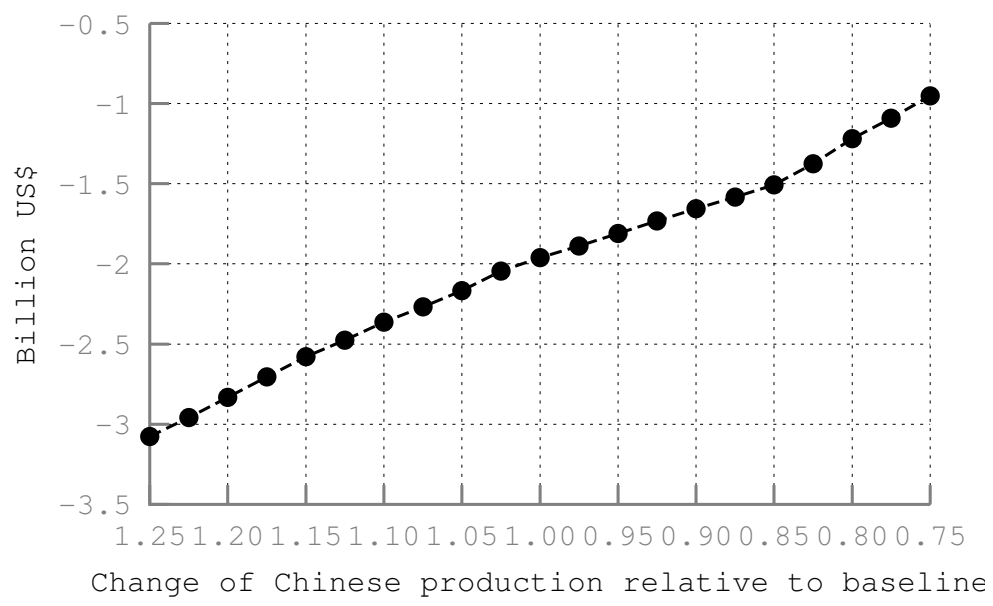

Figure 13: $\Delta W_{C n^{\prime}}$ in billion US\$ as a function of changes in production

Republic expands Rare Earth production. The function increases almost linearly from $\Delta W_{C n^{\prime}}=\mathrm{US} \$-3.1$ billion assuming for a 25 per cent increase to $\Delta W_{C n^{\prime}}=\mathrm{US} \$-1$ billion for a 25 per cent reduction of supply. The reasons are the same as for the price increases. Higher Rare Earth output in China renders the existing trade restrictions tighter in the short run and crowds out market entry in the long run.

\section{Sensitivity Analyses}

Extensive sensitivity checks are conducted to evaluate whether the results are robust. The first part concerns data and assumptions on supply of Rare Earths outside China. It reflects the inherent uncertainty of data from feasibility studies as well as the lack of data on recycling. The second part focuses on data and assumptions on the demand. ${ }^{4}$.

\subsection{Parameters Affecting non-Chinese Supply of Rare Earths}

\subsubsection{Recycling Costs}

Hitherto, recycling costs were assumed prohibitive and thus no recycling takes place. Increasing recycling rates is perceived as an important instrument to reduce dependency on raw material imports, both in the USA and the EU, however (U.S. Department of Energy, 2011; EU Commission, 2011). Thus, I assess how China's market power changes if recycling becomes viable. Phosphors are taken as an example. Rare Earths are used in this application to colorize compact fluorescent lamps and TV screens, among others.

\footnotetext{
${ }^{4}$ Further sensitivity checks regarding the parametrization of the investment cost function can be found in Pothen (2013). They show that the model's results are insensitive to changes in those parameters.
} 
The high prices of Rare Earths used for producing them makes recycling more realistic than in many other applications.

Three scenarios are conducted to assess the impact of introducing recycling of phosphors. They differ from each other in the constant marginal costs of retrieving one $\mathrm{kg}$ of Rare Earths from phosphors. In the first scenario, the costs are assumed to be US $\$ 230$ per kg. This corresponds to the price of a $\mathrm{kg}$ of Rare Earths used to produce phosphors in 2014. Costs of US\$ 173 are assumed in the second scenario. They are further reduced to US\$ 115 in the last scenario. The three scenarios are denoted 230, 173, and 115.

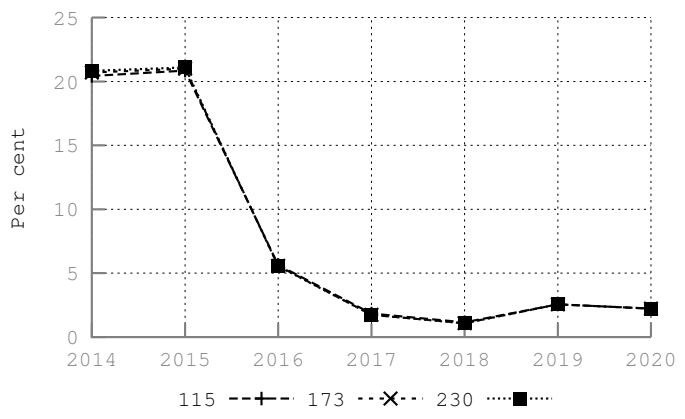

(a)

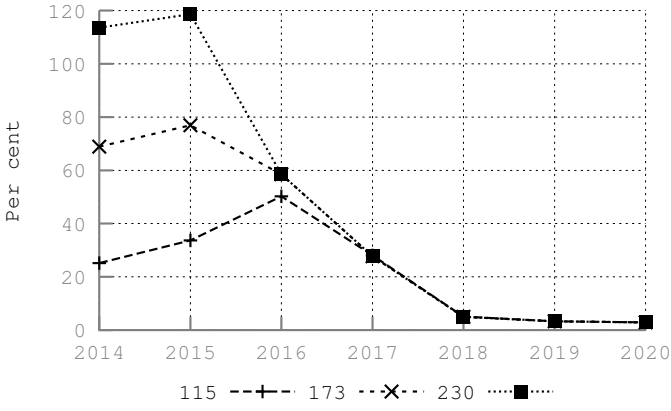

(b)

Figure 14: Change of prices in the rest of the world relative to free trade for LREO $\left(\delta p_{w, t}^{L R E O}\right)$ and HREO $\left(\delta p_{w, t}^{H R E O}\right)$ in per cent(Recycling)

Figure 14 shows recycling costs' effects on $\delta p_{w, t}^{L R E O}$ and $\delta p_{w, t}^{H R E O}$. The left side of figure 14 shows LREO and the right side of figure 14 HREO. $\delta p_{w, t}^{L R E O}$ is independent of the recycling costs for phosphors. Only about 20 per cent of all Rare Earths in phosphors are Light, and phosphors account for a small share of overall Rare Earth consumption in terms of quantity. However, China's ability to exert power on Heavy Rare Earth markets declines strongly, if recycling costs fall, in particular in 2014 and 2015. With costs of US\$ 173 per kg, $\delta p_{w, 2015}^{H R E O}$ drops from 120 to 77 per cent, for example.

Differences between $\delta p_{w, t}^{H R E O}$ in the simulations disappear after 2016. While recycling rates are high before, 43 per cent in 2014 and 36 per cent in 2015 in the 115 scenario, they drop to zero in 2017. New suppliers of primary Rare Earths commence production and force recycling off the market.

Introducing recycling of phosphors reduces welfare losses due to Chinese export restrictions. Figure 15 displays $\Delta W_{C n^{\prime}}$ as a function of recycling costs. Note that reduced environmental externalities due to less mining are neglected and that cost reductions are assumed to be costless themselves. Welfare effects of introducing recycling of phosphors are expected to be substantial. If assuming costs of US\$230 per $\mathrm{kg}$, welfare changes remain the same as in the $\mathrm{BAU}\left(\Delta W_{C n^{\prime}}=\mathrm{US} \$-1.96\right.$ billion). If costs are reduced to US $\$$ 


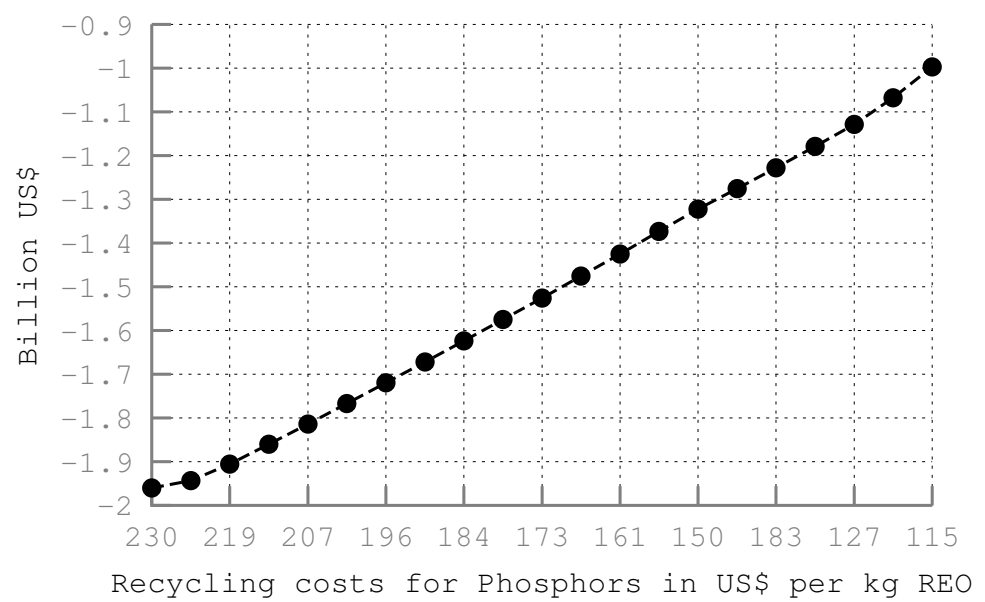

Figure 15: $\Delta W_{C n^{\prime}}$ in billion US\$ as a function of recycling costs

115 per $\mathrm{kg}$, the welfare effect declines to $\Delta W_{C n^{\prime}}=\mathrm{US} \$-1$ billion.

Recycled phosphors provide a source of Heavy Rare Earths while primary supply outside China is still limited. It restricts China's ability to exert market power significantly in the simulations. The results should be interpreted as an upper bound. Assuming constant marginal costs of recycling is crucial, because the recycling rate can grow up to 100 per cent without cost increases. A convex cost function appears more realistic (Tilton, 1999), but data availability does not allow to calibrate such a function. One can, nevertheless, conclude that recycling can a have notable limiting effect on Chinese market power if it is introduced soon.

\subsubsection{Delays in Market Entry}

Extracting and processing Rare Earths involves much less standardized processes than producing other metals. Delays while setting up mines are likely to occur. Previous simulations reveal that market entry of new mining firms is crucial for reducing China's market power. Therefore, I analyze the sensitivity of the results on the assumption that all mines commence production in the year stated in their feasibility studies.

The model is solved per year, thus only discrete delays in years can be simulated. Three scenarios are conducted. The first one is the BAU without delays (shown to ease the comparison). In scenario I, all new non-Chinese suppliers are delayed by one year. The delay is extended to two years in scenario II. Supply and export restrictions in China remain as they are in the BAU. Results are compared to the corresponding free trade simulations.

Figure 16 displays $\delta p_{w, t}^{L R E O}$ and $\delta p_{w, t}^{H R E O}$ in the three scenarios. It illustrates that results 


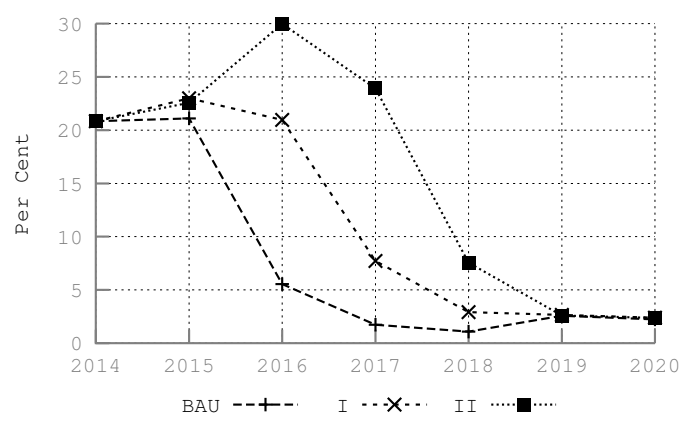

(a)

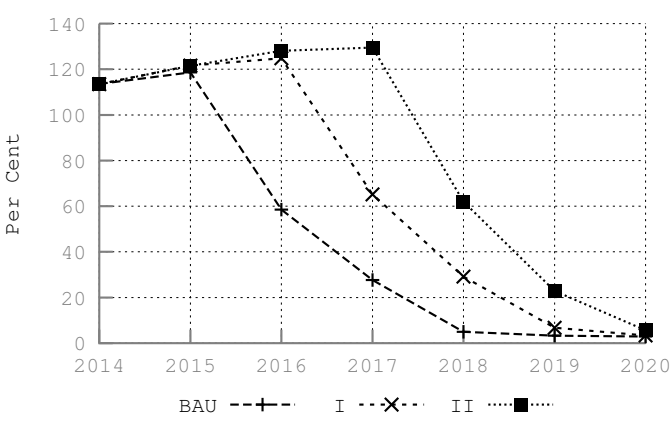

(b)

Figure 16: Change of prices in the rest of the world relative to free trade for LREO $\left(\delta p_{w, t}^{L R E O}\right)$ and HREO $\left(\delta p_{w, t}^{H R E O}\right)$ in per cent (Recycling)

are indeed sensitive to the assumption that mines commence production as scheduled. Interestingly, Chinese market power is not only extended, but its strength increases if delays occur. This is particularly the case for Light Rare Earths (figure 16a). Delays reduce the available capacity between 2015 and 2018 such that they can not keep up with growing demand.

The strengthened Chinese market power is also reflected in higher welfare losses in the rest of the world. When assuming one year delay, $\Delta W_{C n^{\prime}}$ falls from US\$ -1.96 billion to US\$ -2.92 billion. If all new mines are delayed by two years, the welfare effect outside China compared to free trade is $\Delta W_{C n^{\prime}}=\mathrm{US} \$-4.10$ billion.

Delays during the market entry of new Rare Earth supplies extend and aggravate China's market power. Assuming for no delays plausibly underestimates Chinese influence on world markets. If delays do occur, which appears realistic, China could exert market power for a longer time than in the BAU scenario.

\subsubsection{Investment and Extraction Costs}

Investment and extraction costs are calibrated on engineering estimates from feasibility studies. The robustness of the results to changes in costs is assessed using a Monte Carlo Simulation. Feasibility studies present point estimates, but no information about the distribution of the costs. I introduce a triangular distributed random variable $X$ with a lower limit of 0.75 , an upper limit of 1.25 , and a mode of 1 . I draw $n=1000$ samples of $X$, multiply those with the cost estimates and solve the model. The same approach is used in the other Monte Carlo Simulations in this paper.

Figure 17 shows the confidence intervals for $\delta p_{w, t}^{L R E O}$ and $\delta p_{w, t}^{H R E O}$, meaning the interval in which 95 per cent of the results from the simulations fall, as well as the BAU value. 


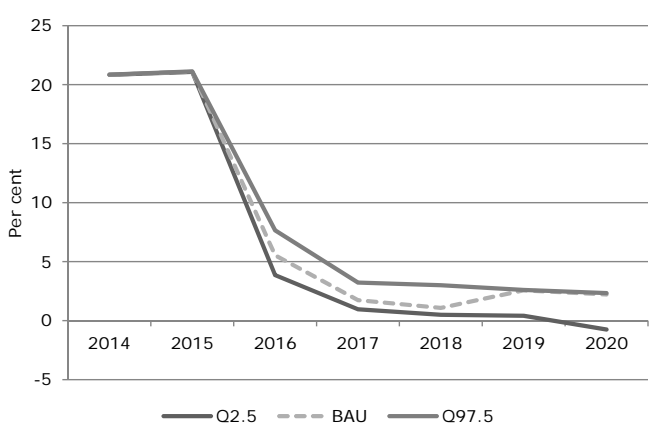

(a)

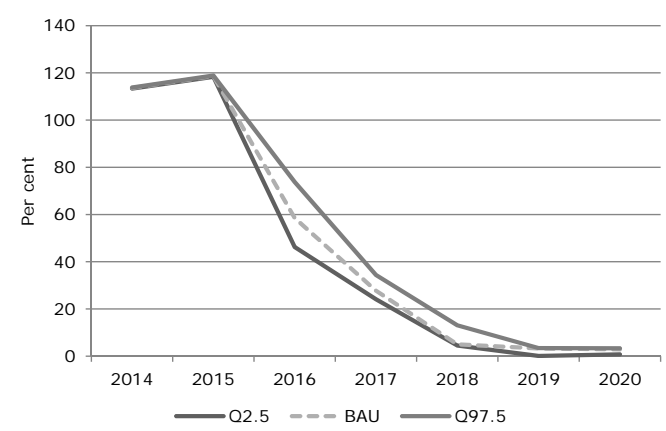

(b)

Figure 17: Confidence intervals for $\delta p_{w, t}^{L R E O}$ (a) and $\delta p_{w, t}^{H R E O}$ (b) (Costs)

Both for Light and Heavy Rare Earths, the cost estimates are almost irrelevant for the prices relative to free trade in 2014 and 2015. Results become more sensitive to mining costs from 2016 on. The BAU scenario appears to be roughly in the middle between the 2.5 percentile and the 97.5 percentile.

\begin{tabular}{llll} 
& Costs & Demand & $\epsilon_{t}$ \\
\hline & & & \\
Mean & -1.99 & -2.05 & -1.97 \\
$Q_{2.5}$ & -2.17 & -2.48 & -2.06 \\
$Q_{97.5}$ & -1.89 & -1.84 & -1.88 \\
$\sigma$ & 0.08 & 0.15 & 0.05
\end{tabular}

Table 5: Results of Monte Carlo Simulations for $\Delta W_{C n^{\prime}}$

Table 5 presents the results on the welfare effects in the rest of the world $\Delta W_{C n^{\prime}}$. It shows the mean, the 2.5 percentile, the 97.5 percentile, and the standard deviation $\sigma$ for the Monte Carlo Simulations on costs, demand prognoses, and the elasticity of demand $\epsilon_{t}$. Column 2 in Table 5 shows results of the Monte Carlo Simulation for investment and extraction costs. 95 per cent of all model runs yield welfare losses between US $\$ 2.17$ billion and US\$ 1.89 billion outside China. On average, $\Delta W_{C n^{\prime}}=\mathrm{US} \$-1.99$ billion which is close to the BAU value of US $\$-1.96$ billion. The standard deviation is US $\$ 80$ million.

The sensitivity analysis indicates that results are not very sensitive to errors in cost estimates. In particular in the 2014 and 2015, the inability of new suppliers to enter the market is more important than the costs. This also explains why welfare effects are not effected strongly. 


\subsection{Parameters Affecting Demand for Rare Earths}

\subsubsection{Demand Prognoses}

The demand functions are calibrated on the prognoses by Kingsnorth (2012). The robustness of the results to changes in demand is scrutinized in this sensitivity analyses. A Monte Carlo Simulation is applied. Again, a triangular distributed random variable (lower limit 0.75 , upper limit 1.25 , mode 1 ) is assumed for, $n=1000$ samples are drawn and multiplied with the demand prognosis.

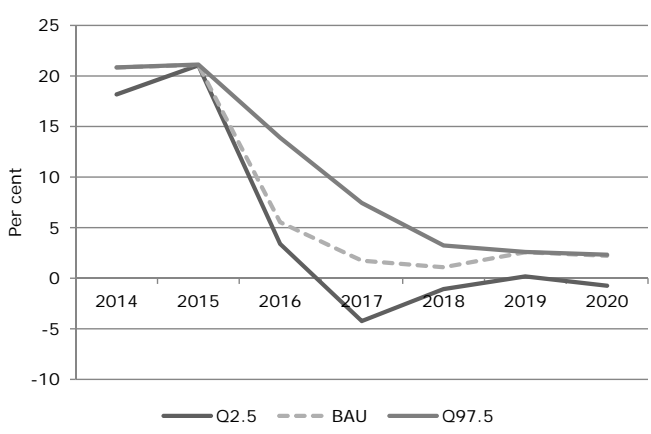

(a)

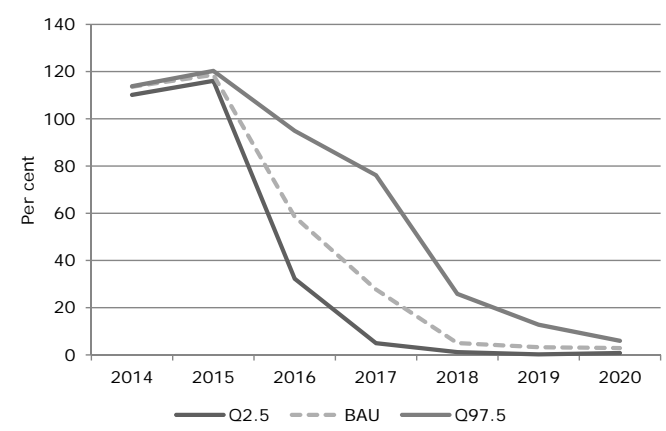

(b)

Figure 18: Confidence intervals for $\delta p_{w, t}^{L R E O}$ (a) and $\delta p_{w, t}^{H R E O}$ (b) (Demand Prognoses)

The confidence intervals around $\delta p_{w, t}^{L R E O}$ and $\delta p_{w, t}^{H R E O}$ shown in figure 18 are rather wide. This is particularly the case from 2016 to 2018. The confidence interval for $\delta p_{w, t}^{H R E O}$ in 2017 , for example, is [5.0, 76.1].

In some cases, demand shocks yield negative $\delta p_{w, t}^{L R E O}$. This phenomenon resembles what was already found when assessing changes in quotas. Export restrictions encourage investment while they are binding, but yield higher capacities than under free trade. Depending on the demand shocks, these capacities can become big enough that China possess negative market power: prices of Rare Earths outside China are lower than they were under free trade.

$\Delta W_{C n^{\prime}}$ is also comparatively sensitive to demand estimations. Column 2 in table 5 reveals that the 95 per cent confidence interval ranges from US $\$-2.48$ billion to US $\$-1.84$ billion. The standard deviation $\sigma$ is US $\$ 150$ million.

The sensitivity of prices and welfare effects to demand shocks is a reasonable result. Demand for Rare Earths is inelastic and thus exogenous changes in demand impact market outcomes strongly. The shocks can seriously affect China's capability to exert market power, both strengthen and weaken it. 


\subsubsection{Price Elasticity of Demand}

The last Monte Carlo Simulation investigates the robustness of the results to the assumption that the price elasticity of demand grows $\epsilon_{t}=-0.3$ to $\epsilon_{t}=-0.5$ in 2020 . It is conducted analogously to the previous ones. $n=1000$ samples are drawn from a triangular distributed random variable (lower limit 0.75, upper limit 1.25, mode 1), multiplied with $\epsilon_{t}$ and the model is solved.

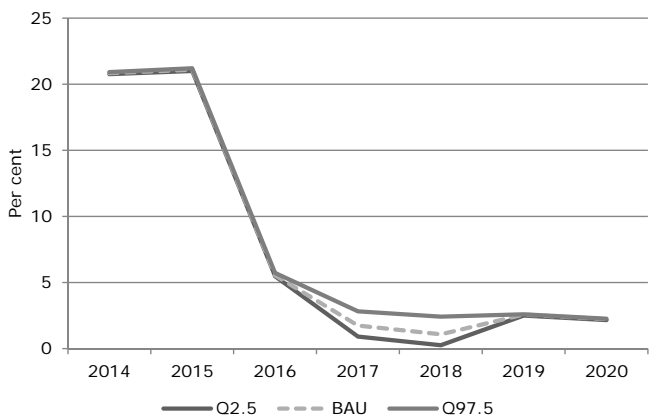

(a)

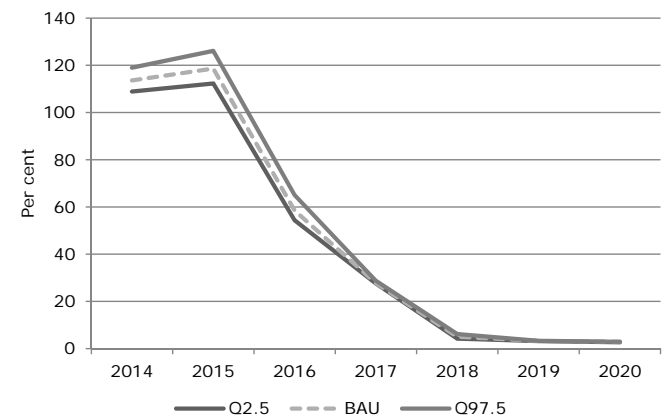

(b)

Figure 19: Confidence intervals for $\delta p_{w, t}^{L R E O}$ (a) and $\delta p_{w, t}^{H R E O}$ (b) (Elasticity of Demand)

Model outcomes are insensitive to the variations of $\epsilon_{t}$. The confidence intervals of LREO and HREO displayed in figure 19 are close to the BAU. $\delta p_{w, t}^{L R E O}$ reacts most sensitive in 2017 and 2018, whereas, are affected mostly in 2014 to 2016. The welfare changes are robust to changes in the elasticity of demand, too. The 95 per cent confidence interval ranges from US $\$-2.06$ billion to US $\$-1.88$ billion, the mean is US $\$-1.97$ billion. All are close to $\Delta W_{C n^{\prime}}=$ US $\$-1.96$ billion in the BAU scenario. The standard deviation of 0.05 is small.

\section{Conclusions}

Rare Earth Elements are crucial inputs for many high-tech industries and Europe, the US, as well as Japan are dependent on importing them from China. This paper quantifies the market power China can exert on Rare Earth markets until 2020 using its export barriers and calculates the corresponding welfare effects.

A dynamic partial equilibrium model for metal markets is developed. It allows for a disaggregated representation of the mining sector and endogenous investment in capacities. The model is calibrated on a novel database on non-Chinese Rare Earth mines. It is, to the best of my knowledge, the first dynamic partial equilibrium model applied on a metal market. Furthermore, this paper presents the first numerical study on Chinese market 
power on Rare Earths.

The results show that China's market power is of temporary nature. The decline of market power differs by type of Rare Earth. Assuming for export restrictions to remain as they are in 2013, the People's Republic increases prices for Light Rare Earths in the rest of the world by 21 per cent compared to free trade in 2014 and 2015. China's capability to exert market power declines quickly thereafter due to market entry of new suppliers.

Market power is more persistent for Heavy Rare Earths. Status-quo export barriers more than double prices outside China in 2014 and 2015. China's market power only vanishes by the end of the decade. Non-Chinese Heavy Rare Earth producers have longer lags until they are able to commence production, thus China's monopoly is less contested by foreign suppliers. Current Chinese export restrictions imply a welfare loss of US\$1.96 billion outside China until 2020.

Altering export restrictions or varying Chinese production yields different levels of exerted market power. Tightening export quotas is very effective in the short run and implies strong welfare effects. But it also induces investment in new capacities, slightly reducing Chinese market power in the long run. Increasing or decreasing export tariffs has less strong but more long-lasting effects. Expanding Chinese Rare Earth output increases market power because it tightens existing export barriers in the short run and crowds out non-Chinese supply in the long run. Introducing recycling attenuates Chinas power on Rare Earth markets, but it has to commence quickly to have major effects.

The results are robust to changes in most key parameters. Varying investment and extraction costs as well as the price elasticity of demand for Rare Earths do not change the model's results strongly. Delays while opening up new mines allow China to exert market power more persistently. Chinese market power depends considerably on the exogenous growth of demand for Rare Earths, however.

Two policy conclusions can be drawn from the results of this paper. Firstly, market forces will plausibly erode Chinese power on Rare Earth markets until the end of the decade. All attempts to introduce recycling, to increase resource efficiency, or to foster substitution need to take this into account. Shortsighted measures relying on high prices levels are likely to be fruitless. Secondly, power on raw material markets is not permanent, but sluggish investment in mining capacities opens up windows of opportunity for nations to influence prices. This calls for a long-term approach in raw material policies. Affected firms, for example, should diversify their inputs to avoid being dependent on a small number of suppliers. 
In this study, Chinese behavior was assumed to be exogenous. This assumptions allows to reduce modeling uncertainties and to get a clear picture of China's leeway to exert market power. To get a deeper understanding of Chinese behavior, optimal policies should be be derived from an optimizing calculus in further research. Models analyzing the optimal behavior of a large resource supplier facing competition from small, price-taking (fringe) suppliers (Salant, 1976; Pindyck, 1978; Groot et al., 2003) could be applied.

\section{References}

Adelman, M. A. (1990). Mineral Depletion, with Special Reference to Petroleum. Review of Economics and Statistics, 72(1):1-10.

Agostini, C. A. (2006). Estimating Market Power in the US Copper Industry. Review of Industrial Organization, 28(1):17-39.

Alonso, E., Sherman, A. M., Wallington, T. J., Everson, M. P., Field, F. R., Roth, R., and Kirchain, R. E. (2012). Evaluating Rare Earth Element Availability: A Case with Revolutionary Demand from Clean Technologies. Environmental Science \& Technology, 46(6):3406-3414.

Cairns, R. D. (2001). Capacity Choice and the Theory of the Mine. Environmental and Resource Economics, 18(1):129-148.

Demailly, D. and Quirion, P. (2008). European Emission Trading Scheme and competitiveness: A case study on the iron and steel industry. Energy Economics, 30(4):2009-2027.

Dirkse, S. P. and Ferris, M. C. (1995). The PATH Solver: A Non-Monotone Stabilization Scheme for Mixed Complementarity Problems. Optimization Methods and Software, $5(2): 123-156$.

Du, X. and Graedel, T. E. (2011). Uncovering the Global Life Cycles of the Rare Earth Elements. Scientific Reports, 1.

EU Commission (2010). Critical raw materials for the EU. Report of the Ad-hoc Working Group on defining critical raw materials. Technical report.

EU Commission (2011). Tackling the Challenges in Commodity Markets and on Raw Materials. $\mathrm{COM}(2011) 25$ final. Technical report.

Fisher, F. M., Cootner, P. H., and Baily, M. N. (1972). An Econometric Model of the World Copper Industry. Bell Journal of Economics, 3(2):568-609.

Fisher, L. and Owen, A. (1981). An economic model of the US aluminium market. Resources Policy, 7(3):150-160.

Groot, F., Withagen, C., and de Zeeuw, A. (2003). Strong time-consistency in the cartelversus-fringe model. Journal of Economic Dynamics and Control, 28(2):287-306.

Gupta, C. K. and Krishnamurthy, N. (2005). Extractive Metallurgy Of Rare Earths. CRC Press.

Gupta, S. (1982). An econometric analysis of the world zinc market. Empirical Economics, $7(1): 213-237$. 
Hatch, G. (2012a). August 2012 Updates To The TMR Advanced Rare-Earth Projects Index.

Hatch, G. (2012b). The Final Chinese Rare-Earth Export-Quota Allocations For 2012.

Hatch, G. (2012c). The First Round Of Chinese Rare-Earth Export-Quota Allocations For 2013.

Hatch, G. (2013a). The Second Round of Chinese Rare-Earth Export-Quota Allocations for 2013.

Hatch, G. (2013b). TMR Advanced Rare-Earth Projects Index. July 24, 2013 Update. Technical report.

Holland, S. P. (2003). Set-up costs and the existence of competitive equilibrium when extraction capacity is limited. Journal of Environmental Economics and Management, 46(3):539-556.

Hurst, C. (2010). Chinas Rare Earth Elements Industry: What Can the West Learn? Technical report, Institute for the Analysis of Global Security.

Kessides, I. N. (1990). Market Concentration, Contestability, and Sunk Costs. Review of Economics and Statistics, 72(4):614-622.

Kingsnorth, D. J. (2012). The Global Rare Earths Industry: A Delicate Balancing Act. Technical report, Deutsche Rohstoffagentur.

Korinek, J. and Kim, J. (2010). Export Restrictions on Strategic Raw Materials and Their Impact on Trade and Global Supply. Trade Policy Working Papers. OECD Publishing.

Lanz, B., Rutherford, T. F., and Tilton, J. E. (2013). Subglobal Climate Agreements and Energy-intensive Activities: An Evaluation of Carbon Leakage in the Copper Industry. World Economy, 36(3):254-279.

Liu, H.-W. and Maughan, J. (2012). China's Rare Earths Export Quotas: Out of the China-Raw Materials Gate, But Past the WTO's Finish Line? Journal of International Economic Law, 15(4):971-1005.

Mackenzie, W. and Cusworth, N. (2007). The Use and Abuse of Feasibility Studies. In AusIMM Project Evaluation Conference, Melbourne, Australia. Australasian Institute of Mining and Metallurgy.

Meyer, L. and Bras, B. (2011). Rare earth metal recycling. In Sustainable Systems and Technology (ISSST), 2011 IEEE International Symposium on, pages 1-6.

Noort, D. J. and Adams, C. (2006). Effective Mining Project Management Systems. In International Mine Management Conference. Australasian Institute of Mining and Metallurgy.

Pindyck, R. S. (1978). Gains to Producers from the Cartelization of Exhaustible Resources. Review of Economics and Statistics, 60(2):238-251.

Pothen, F. (2013). The Metal Resources (METRO) Model. A Dynamic Partial Equilibrium Model for Metal Markets Applied to Rare Earth Elements. Technical report, ZEW Discussion Paper No. 13-112, Mannheim.

Pothen, F. and Fink, K. (2013). The Political Economy of China's Export Restrictions on Rare Earth Elements. Technical report, Unpublished Work.

Rudenno, V. (2009). The Mining Valuation Handbook. Mining and Energy Valuation for Investors and Management. Wrightbooks, 3rd edition. 
Salant, S. W. (1976). Exhaustible Resources and Industrial Structure: A Nash-Cournot Approach to the World Oil Market. Journal of Political Economy, 84(5):1079-1094.

Schüler, D., Buchert, M., Liu, R., Dittrich, S., and Merz, C. (2011). Study on Rare Earths and Their Recycling. Öko-Institut, Darmstadt.

SCIO (2012). Situation and Policies of China's Rare Earth Industry. Technical report.

Slade, M. E. (1980). The effects of higher energy prices and declining ore quality: Copperaluminium substitution and recycling in the USA. Resources Policy, 6(3):223-239.

Tilton, J. E. (1999). The future of recycling. Resources Policy, 25(3):197-204.

Tse, P.-K. (2011). Chinas Rare-Earth Industry. Technical report, U.S. Geological Survey Report 20111042.

U.S. Department of Energy (2011). Critical Materials Strategy. Technical report.

U.S. Geological Survey (2011). Rare Earth Elements. End Use and Recyclability. Technical report, U.S. Geological Survey.

U.S. Geological Survey (2012). Global Rare Earth Oxide (REO) Production Trends. Technical report.

U.S. Geological Survey (2013). Mineral Commodity Summaries 2013 - Rare Earths. Technical report.

Winters, L. (1995). Liberalizing European steel trade. European Economic Review, 39(34):611-621.

WTO (2012). China Measures Related to the Exportation of Rare Earths, Tungsten and Molybdenum. Request for Consultations by the United States. Technical report, $\mathrm{WT} / \mathrm{DS} 431 / 6$.

Wübbeke, J. (2013). Rare earth elements in China: Policies and narratives of reinventing an industry. Resources Policy, 38(3):384-394. 